\title{
UM ESTUDO SOBRE AS COMPETÊNCIAS DE EMPREENDEDORES DO MUNICÍPIO DE SÃO JOSÉ DOS CAMPOS - SP
}

\author{
Isabel Degen Alendes ${ }^{1}$ \\ Laís Carvalho Barbosa ${ }^{2}$ \\ Wanda Ferreira Martins Santos ${ }^{3}$ \\ Érica Reis Costa Carvalho ${ }^{4}$
}

Resumo: Levando em consideração o âmbito empresarial e a criação de novas ideias, os conceitos de competência e empreendedorismo parecem reunir-se em apenas um. Desta maneira, percebeu-se a necessidade de analisar uma parcela de empreendedores do município de São José dos Campos (SP) para que assim, fosse identificado o domínio predominante entre três categorias de competências, sendo elas técnicas, estratégicas e comportamentais. Para tanto, foi realizado uma pesquisa quantitativa com vários empreendedores através de um formulário de pesquisa. Após serem avaliados, os resultados mostraram que dentre as competências técnicas houve um empate entre o domínio básico e avançado. Já nas competências comportamentais e estratégicas prevalece o domínio intermediário. Logo, conclui-se que apesar de mostrarem-se aptos para gerir organizações empresariais, ainda devem explorar mais suas competências a fim de atingir melhores resultados em suas organizações.

Palavras-chave: Competências; Empreendedorismo.

\footnotetext{
1 Curso Técnico em Administração/Fundação Valeparaibana de Ensino, Colégio Técnico "Antônio Teixeira Fernandes", Brasil. E-mail: bel.alendes@gmail.com.

2 Curso Técnico em Administração/Fundação Valeparaibana de Ensino, Colégio Técnico "Antônio Teixeira Fernandes", Brasil. E-mail: laiscbarbosa@hotmail.com.br.

3 Curso Técnico em Administração/Fundação Valeparaibana de Ensino, Colégio Técnico "Antônio Teixeira Fernandes", Brasil. E-mail: wandafmartins@hotmail.com.

4 Curso Técnico em Administração/Fundação Valeparaibana de Ensino, Colégio Técnico "Antônio Teixeira Fernandes", Brasil. E-mail: ericareis@univap.br.
} 